\title{
Effect of diets with different energy and lipase levels on performance, digestibility and carcass trait in broilers
}

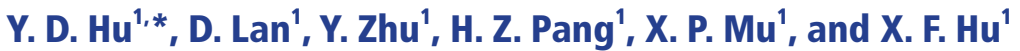

* Corresponding Author: Y. D. Hu Tel: +86-02886291265, Fax: +86-02886291265, E-mail:13982@sicau.edu.cn

1 Farm Animal Genetic Resources Exploration and Innovation Key Laboratory of Sichuan Province, Sichuan Agricultural University, Ya'an, Sichuan 625014, China

\section{ORCID}

Y. D. Hu

https://orcid.org/0000-0003-3293-568X

D. Lan

https://orcid.org/0000-0003-0620-2482

Y. Zhu

https://orcid.org/0000-0001-9277-9071

H. Z. Pang

https://orcid.org/0000-0002-1695-4410

X. P. Mu

https://orcid.org/0000-0002-6527-2758

X.F. Hu

https://orcid.org/0000-0001-7138-7933

Submitted Oct 12, 2017; Revised Nov 18, 2017; Accepted Dec 18, 2017
Objective: A 28-d trial was conducted to evaluate the effect of diets with different energy and lipase levels on performance, nutrient digestibility, serum profiles, gut health, and carcass quality in broilers.

Methods: A total of 720 one-day-old male Ross 308 broilers ( $45.4 \pm 0.5 \mathrm{~g}$ ) were randomly assigned to one of the following four treatments: i) RET, reduced energy treatment (metabolizable energy $=2,950$ and 3,100 kcal $/ \mathrm{kg}$ for starter and finisher diet), ii) BDT, basal diet treatment (metabolizable energy $=3,050$ and 3,200 kcal $/ \mathrm{kg}$ for starter and finisher diet, iii) RET015, RET+0.15 g/kg lipase, and iv) RET03, RET+0.3 g/kg lipase. There were 10 replications (cages) per treatment with 18 birds per cage.

Results: During d 1 to 14, broilers fed BDT, RET015, and RET03 diets had higher $(\mathrm{p}<0.05)$ body weight gain than those fed RET diet. During $\mathrm{d} 1$ to 14,15 to 28 and the overall experiment, feed conversion ratio in RET03 treatment was lower $(\mathrm{p}<0.05)$ compared with RET treatment. On $\mathrm{d} 14$, the apparent total tract digestibility (ATTD) of dry matter (DM), ether extract $(\mathrm{EE})$, and gross energy in RET03 treatment was higher $(\mathrm{p}<0.05)$ than those in RET treatment, while the ATTD of $\mathrm{N}$ was increased $(\mathrm{p}<0.05)$ by RET03 treatment. On $\mathrm{d} 28$, broilers fed RET03 diet had higher $(\mathrm{p}<0.05)$ ATTD of DM than those fed RET and RET015 diets, while the ATTD of EE in BDT and RET03 treatments was increased $(p<0.05)$ compared with RET and RET015 treatments. Broilers fed RET03 diet had higher villus height (VH) and $\mathrm{VH}$ :crypt depth (CD) ratio than those fed RET and BDT diets. The activity of pancreatic lipase in BDT and RET03 treatments was higher $(\mathrm{p}<0.05)$ than that in RET treatment. Conclusion: Taken together, lipase supplementation $(3,000 \mathrm{U} / \mathrm{kg}$ feed) increased growth performance, nutrient digestibility, $\mathrm{VH}, \mathrm{VH}: \mathrm{CD}$ ratio and lipase activity, but decreased triglyceride, low-density lipoprotein cholesterol and the abdominal fat percentage in broilers fed reduced energy diet.

Keywords: Broiler; Digestibility; Energy; Lipase; Performance

\section{INTRODUCTION}

Increased metabolizable energy (ME) was required by the continuous genetic improvements in broiler performance [1]. Dietary energy concentration acts with other nutrients and greatly influencs the intake of all other nutrients in broilers [2]. Moreover, the body composition of broilers may also be influenced by energy intake [3]. It was commonly accepted that the high energy diet required by broilers was fulfilled by the addition of lipids (fats and oils) because lipids, as the main energy source for broilers, had the highest caloric value among all the nutrients.

The digestibility of fat and oils depends on their chemical and physical characteristics of their constituent fatty acids. Previous studies showed that the degree of saturation of fatty acids and their chain length influenced ME in broilers [4-5]. Fats rich in unsaturated fatty 
acids were better digested and absorbed than saturated fats [6]. Therefore, a higher degree of saturation and increasing fatty acid chain length led to poorer digestibility of the lipid source. Furthermore, the source and type of lipids, the composition of the diets, and the age of birds can also affect lipids digestion [7].

The digestion and absorption capacity of lipids in young broilers is poor because newly hatched chicks may be deficient in natural lipase production [8]. The specific activity of lipase need several weeks after hatching to increase in broilers [9]. The immature physiological functions may also influence the efficiency of lipid digestion in young chickens [8]. In addition, tallow had a lower fat digestibility and ME content than vegetable oils due to its higher content of long-chain saturated fatty acids.

Therefore, there are some problems regarding lipids utilization and digestion in broilers. The largest proportion and cost of broiler diets are dietary energy, especially those derived from lipids. If the digestibility of lipids can be improved, the feed production costs may be reduced to increase the broiler performance or even maintain the same level with lower lipid content [10]. In general, there were two ways to solve this problem. On the one hand, emulsifiers (lysophospholipids, lysolecithin, bile salts, or sodium stearoyl-2-lactylate) were used to increase the lipid digestibility because they increased the active surface of lipid droplets and promote incorporation of fatty acids into micelles $[7,11,12]$. On the other hand, one approach was the supplementation of diets offered to broilers with appropriate exogenous lipase [13]. Lipase (EC3.1.1.3), triacylglyceryl acylase, is any enzyme involved in catalysis and the hydrolysis of lipids. The application of adding exogenous lipase in boilers' diets was rare compared with the studies about phytase and non-starch polysaccharide enzymes. Increased dietary concentration of lipase (25,000 U/g lipase; $0 \%$ to $1.125 \%)$ caused a linear reduction of feed intake (FI) and body weight gain (BWG) during $\mathrm{d} 1$ to 21 , while it did not affect growth or FI from 21 to $42 \mathrm{~d}$ or 1 to $42 \mathrm{~d}$ in broilers [14]. The supplementation of soy lecithin alone or in combination with lipase enzyme in broilers diets (100 U/kg feed) exerted beneficial effects on performance, carcass quality, oxidative stability, and thereby increasing shelf life of meat during refrigerated storage and profitability [15].

As there were inconsistent results from the previous limited studies, the objective of this research was to evaluate the effect of diets with different energy and lipase levels on performance, nutrient digestibility, serum profiles, relative organ weight, jejunum villi histology, digestive enzyme activities and carcass quality in broilers. Furthermore, several studies have identified positive effects of exogenous enzymes in poultry fed low nutrition density diets $[16,17]$. Therefore, it was hypothesized that lipase might have a beneficial effect on broilers when they were fed reduced energy diet.

\section{MATERIALS AND METHODS}

\section{Sources of lipase}

The acidic heat-resistant lipase (microbial source) used in this study was manufactured by Habio (Mianyang, China) and guaranteed to contain 10,000 U/g. It was patented in China and the patent No. is ZL201210121105.3. One unit of lipase is the enzyme activity required to release $1 \mu \mathrm{mol}$ of free fatty acid from tricaprylin substrate per minute at $40^{\circ} \mathrm{C}$ and $\mathrm{pH}$ 5.5.

\section{Animals, housing, and treatments}

The Animal Welfare Committee of Sichuan Agricultural University approved the animal care protocol used for this experiment. A total of 720 male Ross 308 broilers (one $\mathrm{d}$ old) with an average initial body weight (BW) of $45.4 \pm 0.5 \mathrm{~g}$ were blocked on the basis of initial BW according to a randomized complete block design. The treatments included: i) RET, reduced energy treatment $(\mathrm{ME}=2,950$ and $3,100 \mathrm{kcal} / \mathrm{kg}$ for starter and finisher diet), ii) $\mathrm{BDT}$, basal diet treatment ( $\mathrm{ME}=$ 3,050 and 3,200 kcal/kg for starter and finisher diet, iii) RET015, RET $+0.15 \mathrm{~g} / \mathrm{kg}$ lipase, and iv) RET03, RET+0.3 g/kg lipase. There were 10 replications (cages) per treatment with 18 broilers per cage. The lipase was added at the expense of corn. The diets were formulated to provide all of the nutrients to meet or exceed NRC [18] requirements for broilers (Table 1). A 2-phase feeding program was used: a starter diet from d 1 to 14 and a finisher diet from $\mathrm{d} 15$ to 28 . The experiment lasted for $28 \mathrm{~d}$. All of the broilers were raised in an environmentally controlled room with stainless steel cages of identical size (1.75 $\times 1.55 \mathrm{~m}$ ). The floor was made of wire mesh. The environmental temperature began at $33^{\circ} \mathrm{C}$ for the first $3 \mathrm{~d}$, and was then reduced to $24^{\circ} \mathrm{C}$ until the end of the experiment and the relative humidity was around $60 \%$. Broilers received diets and water ad libitum. Mortality was recorded as it occurred, and birds were inspected daily for any health-related problems.

\section{Experimental procedures, sampling, and analysis}

The broilers were weighed by cage and FI was recorded on $\mathrm{d}$ 1,14 , and 28 , which were then used to calculate BWG, FI, and feed conversion ratio (FCR).

From d 8 to 14 and 22 to 28 , broilers were fed diets mixed with chromic oxide $(0.2 \%)$ as an indigestible marker to determine the apparent total tract digestibility (ATTD) for nutrient digestibility [19]. On d 14 and 28, all plates under each cage were cleaned, and excreta samples were collected for $24 \mathrm{~h}$, pooled within a cage, then stored frozen at $-20^{\circ} \mathrm{C}$ for the determination of nutrient digestibility. The ATTD of dry matter (DM) and $\mathrm{N}$ was calculated using indirect-ratio methods. The gross energy (GE) in the feed and excreta was determined using a calorimeter (Mode1241, Parr Instrument Co., Moline, IL, USA). The digestibility was calculated using the following formula: digestibility $(\%)=(1-[\{\mathrm{Nf} \times \mathrm{Cd}\} /\{\mathrm{Nd} \times \mathrm{Cf}\}]) \times 100$, where 
Table 1. Diet composition (as-fed basis)

\begin{tabular}{|c|c|c|c|c|}
\hline \multirow{2}{*}{ Items } & \multicolumn{2}{|c|}{ Starter (d 1 to 14$)$} & \multicolumn{2}{|c|}{ Finisher (d 15 to 28 ) } \\
\hline & $\mathrm{RE}^{1)}$ & $\mathrm{BD}^{1)}$ & RE & BD \\
\hline \multicolumn{5}{|l|}{ Ingredients (\%) } \\
\hline Corn & 58.85 & 56.16 & 60.82 & 59.95 \\
\hline Soybean meal (CP 44\%) & 31.20 & 31.50 & 28.00 & 25.45 \\
\hline Corn gluten meal (CP 60\%) & 4.37 & 4.65 & 3.14 & 5.02 \\
\hline Tallow & 1.35 & 3.50 & 4.00 & 5.50 \\
\hline Limestone & 1.00 & 1.00 & 1.00 & 1.00 \\
\hline Dicalcium phosphate & 2.08 & 2.08 & 1.89 & 1.93 \\
\hline $\mathrm{NaCl}$ & 0.40 & 0.40 & 0.40 & 0.40 \\
\hline L-lys·HCl (24\%) & 0.20 & 0.20 & 0.20 & 0.20 \\
\hline DL-methionine (99\%) & 0.20 & 0.20 & 0.20 & 0.20 \\
\hline L-threonine $(98.5 \%)$ & 0.15 & 0.15 & 0.15 & 0.15 \\
\hline Vitamin premix ${ }^{2)}$ & 0.10 & 0.10 & 0.10 & 0.10 \\
\hline Trace mineral premix ${ }^{3)}$ & 0.10 & 0.10 & 0.10 & 0.10 \\
\hline \multicolumn{5}{|l|}{ Analytical composition } \\
\hline ME (kcal/kg) $)^{4)}$ & 2,950 & 3,050 & 3,100 & 3,200 \\
\hline Crude protein (\%) & 22.04 & 22.03 & 19.97 & 19.98 \\
\hline $\mathrm{EE}(\%)$ & 4.24 & 6.25 & 6.77 & 8.25 \\
\hline Total lysine (\%) & 1.18 & 1.17 & 1.06 & 1.05 \\
\hline Methionine (\%) & 0.58 & 0.59 & 0.54 & 0.55 \\
\hline $\mathrm{Ca}(\%)$ & 0.94 & 0.93 & 0.89 & 0.88 \\
\hline Total P (\%) & 0.73 & 0.72 & 0.68 & 0.67 \\
\hline \multicolumn{5}{|l|}{ Fatty acid profile (\%) } \\
\hline C14:00 & 0.06 & 0.13 & 0.14 & 0.16 \\
\hline C16:00 & 10.14 & 10.48 & 10.68 & 10.90 \\
\hline C16:01 & 0.13 & 0.22 & 0.22 & 0.24 \\
\hline C18:00 & 2.01 & 2.31 & 2.38 & 2.43 \\
\hline C18:01 & 21.96 & 22.40 & 22.70 & 23.21 \\
\hline C18:02 & 51.25 & 50.20 & 50.10 & 50.31 \\
\hline C18:03 & 2.61 & 2.60 & 2.71 & 2.49 \\
\hline C18:04 & 0.80 & 0.79 & 0.82 & 0.82 \\
\hline SFA & 12.21 & 12.92 & 13.20 & 13.49 \\
\hline PUFA & 54.66 & 53.59 & 53.63 & 52.62 \\
\hline MUFA & 22.09 & 22.62 & 22.92 & 23.45 \\
\hline
\end{tabular}

$\mathrm{CP}$, crude protein; $\mathrm{ME}$, metabolizable energy; $\mathrm{EE}$, ether extract; $\mathrm{SFA}$, saturated fatty acid; PUFA, polyunsaturated fatty acid; MUFA, monounsaturated fatty acid.

1) $B E$, basal diet; $R E$, reduced energy diet; replaced the same amount of corn with lipase to create dietary treatments.

2) Provided per kilogram of diet: $15,000 \mathrm{IU}$ of vitamin $\mathrm{A}, 3,750 \mathrm{IU}$ of vitamin $D_{3}$, $37.5 \mathrm{mg}$ of vitamin $\mathrm{E}_{2} 2.55 \mathrm{mg}$ of vitamin $\mathrm{K}_{3}, 3 \mathrm{mg}$ of thiamin, $7.5 \mathrm{mg}$ of riboflavin, $4.5 \mathrm{mg}$ of vitamin $B_{6}, 24 \mu \mathrm{g}$ of vitamin $B_{12}, 51 \mathrm{mg}$ of niacin, $1.5 \mathrm{mg}$ of folic acid, $0.2 \mathrm{mg}$ of biotin, and $13.5 \mathrm{mg}$ of pantothenic acid.

3) Provided per kilogram of diet: $37.5 \mathrm{mg} \mathrm{Zn} \mathrm{(as} \mathrm{ZnSO}_{4}$ ); $37.5 \mathrm{mg} \mathrm{Mn}\left(\mathrm{as} \mathrm{MnO}_{2}\right.$ ); $37.5 \mathrm{mg} \mathrm{Fe}\left(\mathrm{as} \mathrm{FeSO}_{4} \cdot 7 \mathrm{H}_{2} \mathrm{O}\right.$ ); $3.75 \mathrm{mg} \mathrm{Cu}\left(\right.$ as $\mathrm{CuSO}_{4} \cdot 5 \mathrm{H}_{2} \mathrm{O}$ ); $0.83 \mathrm{mg} \mathrm{I}$ (as Kl); and $0.23 \mathrm{mg} \mathrm{Se}\left(\mathrm{as} \mathrm{Na}_{2} \mathrm{SeO}_{3} \cdot 5 \mathrm{H}_{2} \mathrm{O}\right)$.

${ }^{4)}$ Calculated value.

$\mathrm{Nf}=$ nutrient concentration in excreta $(\% \mathrm{DM}), \mathrm{Nd}=$ nutrient concentration in diet $(\% \mathrm{DM}), \mathrm{Cf}=$ nutrient concentration in $\operatorname{diet}(\% \mathrm{DM})$, and $\mathrm{Cd}=$ nutrient concentration in excreta (\% DM).

Before chemical analysis, excreta samples were dried at $57^{\circ} \mathrm{C}$ for $72 \mathrm{~h}$, after which they were ground to pass through a 1-mm screen. Experimental feeds were analyzed for crude protein, calcium, and phosphorus and ether extract (EE) [20]. The amino acid profile of diets was analyzed by HPLC (Hitachi L-8800 Amino Acid Analyzer, Tokyo, Japan) as previously described [21]. All samples were hydrolyzed at $110^{\circ} \mathrm{C}$ for $24 \mathrm{~h}$ in $6 \mathrm{~N} \mathrm{HCl}$ before analysis. Methionine was analyzed as Met sulfone after cold performic acid oxidation overnight before hydrolysis. The feces were analyzed for DM, N, and EE [20]. Chromium was analyzed via UV absorption spectrophotometry (Shimadzu, UV-1201, Kyoto, Japan) [22]. The GE was determined by measuring the heat of combustion in the samples using a Parr 6100 oxygen bomb calorimeter (Parr instrument Co., USA).

The fatty acid content in the feed was the mean of 2 replications, and the total fatty acids were analyzed by gas chromatography with a flame ionization detector (Hewlett Packard 5890 Series II, Palo Alto, CA, USA). The fatty acid methyl esters were separated using a Supelcowax-10 fused silica capillary column (100 m×0.32 mm×0.25 $\mu \mathrm{m}$; Supelco, Inc., Bellefonte, PA, USA), with $1.2 \mathrm{~mL} / \mathrm{min}$ of helium flow. The oven temperature was increased from $220^{\circ} \mathrm{C}$ to $240^{\circ} \mathrm{C}$, at the rate of $2^{\circ} \mathrm{C} / \mathrm{min}$. Temperatures of the injector and detector were $240^{\circ} \mathrm{C}$ and $250^{\circ} \mathrm{C}$, respectively. The peak of fatty acids was identified by comparing the retention time and peak area of each fatty acid standard, respectively. The content of each fatty acid was expressed as a percentage of the sum of all of the fatty acids analyzed.

On d 14, four broilers were randomly selected from each cage and blood samples were collected from the jugular vein into a sterile syringe and stored at $-4^{\circ} \mathrm{C}$. Blood samples were then centrifuged at $3,000 \times \mathrm{g}$ for $15 \mathrm{~min}$ and serum was separated. The total cholesterol (TC), high-density lipoprotein cholesterol (HDL-C), low-density lipoprotein cholesterol (LDL$\mathrm{C}$ ), and triglyceride (TG) in the serum samples were analyzed with an autoanalyzer (Automatic Biochemical Analyzer, RA1000; Bayer Corp., Tarrytown, NY, USA) using colorimetric methods [7]. At the end of the experiment, the same broilers from which blood was taken on d 14 were weighed individually, their blood sampled, and then sacrificed by cervical dislocation. After blood collection, the sample was transferred immediately into a vacuum tube (Becton Dickinson Vacutainer Systems, Franklin Lakes, NJ, USA) and stored at $-4^{\circ} \mathrm{C}$. The gizzard, breast muscle, bursa of fabricius, liver, spleen, thymus, and abdominal fat were then removed and weighted. Organ weight was expressed as a percentage of BW. The breast muscle lightness $\left(L^{*}\right)$, redness $\left(a^{*}\right)$, and yellowness $\left(b^{*}\right)$ values were determined (Minolta CR410 Chromameter; Konica Minolta Sensing Inc., Osaka, Japan). Duplicate $\mathrm{pH}$ values for each muscle were measured using a $\mathrm{pH}$ meter (Fisher Scientific, Pittsburgh, PA, USA). The water-holding capacity (WHC) was measured with the methods previously described [23]. Briefly, a $0.3-\mathrm{g}$ sample was pressed with $3,000 \mathrm{~g}$ weight for $3 \mathrm{~min}$ at $26^{\circ} \mathrm{C}$ on a $125-\mathrm{mm}$-diameter piece of filter paper. The areas of the 
pressed sample and the expressed moisture were delineated and then determined using a digitizing area-line sensor (MT10S; M.T. Precision Co. Ltd., Tokyo, Japan). The ratio of water: meat area was then calculated, giving a measure of WHC (a smaller ratio indicates increased WHC). Drip loss was measured using approximately $2 \mathrm{~g}$ of muscle sample according to the plastic bag method previously described [24].

On d 28, a section of mid-jejunum was collected from four birds per cage. The jejunum samples were fixed in $10 \%$ neutral buffered formalin, processed by standard paraffin sectioning, and stained with hematoxylin-eosin. The slides were examined under a light microscope. Intestinal morphological measurements included the following 3 indices: villus height $(\mathrm{VH})$, crypt depth (CD), and VH:CD. Measurements of VH were taken from the top of the villus to the valley between villi, and measurements of $\mathrm{CD}$ were taken from the valley to the basolateral membrane. Mean values of $\mathrm{VH}, \mathrm{CD}$, and their ratio were calculated. In addition, pancreas and small intestine mucosa were collected from the same birds per cage for determining digestive enzyme activities. Collected pancreas and small intestine mucosa were dissolved in phosphate-buffered saline, respectively, to a concentration of $0.2 \mathrm{~g} / \mathrm{mL}$. The mixture was then homogenized, centrifuged at $1,400 \times \mathrm{g}$ at $4^{\circ} \mathrm{C}$ for $15 \mathrm{~min}$, and the clear supernatant was separated for subsequent enzyme activity analysis. For pancreatic samples, the concentration of total protein, amylase, lipase, and trypsin were determined according to manufacturer instructions (Shanghai Shensuo Youfu Medical Diagnostics Co. Ltd., Shanghai, China). For mucosal samples, the activity of sucrase and maltase was determined as previously described [25]. One unit of sucrase activity is defined as the amount of enzyme that cleaves sucrose to generate $1.0 \mu \mathrm{mol}$ glucose per $\mathrm{mg}$ of protein at $37^{\circ} \mathrm{C}$. One unit of maltase activity is defined as the amount of enzyme that cleaves maltose to generate $1.0 \mu \mathrm{mol}$ glucose per mg of protein at $37^{\circ} \mathrm{C}$. One unit is the amount of amylase that cleaves ethylidene-pNP-g7 to generate $1.0 \mu \mathrm{mol}$ p-nitrophenol per $\mathrm{mg}$ of protein per minute at $25^{\circ} \mathrm{C}$. One unit is the amount of trypsin that cleaves the substrate yielding $1.0 \mu \mathrm{mol}$ p-NA per mg of protein per minute at $25^{\circ} \mathrm{C}$. One unit is the amount of lipase that generates $1.0 \mu \mathrm{mol}$ glycerol from tryglycerides per $\mathrm{mg}$ of protein per minute at $25^{\circ} \mathrm{C}$. All determinations were performed in duplicates.

\section{Statistical analysis}

Data were analyzed using the general linear model Procedure of SAS as a randomized complete block design (SAS Inst. Inc., Cary, NC, USA) with the cage being considered as the experimental unit. Differences among treatment means were determined using Tukey's range test. Variability in the data was expressed as the standard error means and a probability level of $\mathrm{p}<0.05$ was considered to be statistically significant.

\section{RESULTS}

\section{Growth performance}

During $\mathrm{d} 1$ to 14, BWG in broilers fed the BDT, RET015, and RET03 diets was greater $(p<0.05)$ than those fed the RET diet (Table 2). Broilers fed RET03 diets had lower $(\mathrm{p}<0.05)$ FCR compared with those fed RET diet. No effects were observed in FI among dietary treatments ( $p>0.05)$. During $d 15$ to 28 and the overall experiment, FCR was decreased $(\mathrm{p}<0.05)$ by RET03 treatment compared with RET treatment, while BWG and FI were not affected $(\mathrm{p}>0.05)$.

\section{Nutrient digestibility}

On d 14, broilers fed RET03 diet had higher $(\mathrm{p}<0.05)$ ATTD of DM, EE, and GE than those fed RET diet (Table 3). The ATTD of $\mathrm{N}$ was increased $(\mathrm{p}<0.05)$ by RET03 treatment compared with other treatments. On d 28, the ATTD of DM in broilers fed the RET03 diet was higher $(p<0.05)$ than those fed the RET and RET015 diets. Broilers fed the BDT and RET03 diet had higher $(\mathrm{p}<0.05)$ ATTD of EE compared with those fed RET and RET015 diets. There was no difference ( $p>0.05)$ in ATTD of N or GE among treatments.

\section{Serum profiles}

On d 14, the concentration of TG and LDL-C in RET, RET015, and RET03 treatments were decreased $(\mathrm{p}<0.05)$ compared with BDT treatment (Table 4), and LDL-C concentration in RET03 treatment was also lower $(\mathrm{p}<0.05)$ than that in RET treatment. Broilers fed RET015 and RET03 diets had lower $(\mathrm{p}<0.05)$ levels of TC than those fed BDT diet. Dietary treatments did not affect $(p>0.05)$ the concentration of HDL-C. On $d 28$, the TC

Table 2. Effect of diets with different energy and lipase levels on growth performance in broilers ${ }^{1)}$

\begin{tabular}{lcccccc}
\hline Item & RET $^{2)}$ & BDT $^{2)}$ & RET015 $^{2)}$ & RET03 $^{2)}$ & SEM & p-value \\
\hline d 1 to 14 & & & & & & \\
$\quad$ BWG (g) & $397^{\mathrm{b}}$ & $416^{\mathrm{a}}$ & $415^{\mathrm{a}}$ & $422^{\mathrm{a}}$ & 4.13 & 0.02 \\
FI (g) & 480 & 492 & 490 & 487 & 7.02 & 0.38 \\
$\quad$ FCR & $1.209^{\mathrm{a}}$ & $1.182^{\text {ab }}$ & $1.180^{\text {ab }}$ & $1.154^{\mathrm{b}}$ & 0.019 & 0.03 \\
d 15 to 28 & & & & & & \\
$\quad$ BWG (g) & 1,059 & 1,087 & 1,066 & 1,102 & 21.15 & 0.40 \\
FI (g) & 1,677 & 1,664 & 1,640 & 1,625 & 25.22 & 0.28 \\
FCR & $1.583^{\mathrm{a}}$ & $1.531^{\text {ab }}$ & $1.538^{\text {ab }}$ & $1.474^{\mathrm{b}}$ & 0.023 & 0.04 \\
d 1 to 28 & & & & & & \\
BWG (g) & 1,456 & 1,503 & 1,481 & 1,524 & 22.01 & 0.07 \\
FI (g) & 2,157 & 2,156 & 2,130 & 2,112 & 23.31 & 0.19 \\
FCR & $1.481^{\mathrm{a}}$ & $1.434^{\text {ab }}$ & $1.438^{\text {ab }}$ & $1.385^{\mathrm{b}}$ & 0.019 & 0.03 \\
\hline
\end{tabular}

SEM, pooled standard error of the means; BWG, body weight gain; Fl, feed intake; $F C R$, feed conversion ratio; $M E$, metabolizable energy.

1) Each mean represents 10 replications with 18 chicks per replication.

2) $\mathrm{RET}$, reduced energy treatment (ME $=2,950$ and 3,100 kcal $/ \mathrm{kg}$ for starter and finisher diet); BDT, basal diet treatment (ME = 3,050 and 3,200 kcal $/ \mathrm{kg}$ for starter and finisher diet); RET015, RET+0.15 g/kg lipase; RET03, RET+0.3 g/kg lipase.

${ }^{\mathrm{ab}}$ Means in the same row with different superscripts differ $(p<0.05)$. 
Table 3. Effect of diets with different energy and lipase levels on nutrient digestibility in broilers ${ }^{1)}$

\begin{tabular}{ccccccc}
\hline Item (\%) & RET $^{2)}$ & BDT $^{2)}$ & RET015 $^{2)}$ & RET03 $^{2)}$ & SEM & p-value \\
\hline d 14 & & & & & & \\
DM & $72.99^{\mathrm{b}}$ & $74.33^{\mathrm{ab}}$ & $73.90^{\mathrm{b}}$ & $75.96^{\mathrm{a}}$ & 0.40 & 0.02 \\
N & $65.53^{\mathrm{b}}$ & $65.63^{\mathrm{b}}$ & $65.85^{\mathrm{b}}$ & $67.39^{\mathrm{a}}$ & 0.33 & 0.04 \\
EE & $77.02^{\mathrm{b}}$ & $78.23^{\mathrm{ab}}$ & $78.38^{\mathrm{ab}}$ & $79.47^{\mathrm{a}}$ & 0.48 & 0.03 \\
GE & $80.10^{\mathrm{b}}$ & $81.19^{\mathrm{ab}}$ & $81.08^{\mathrm{ab}}$ & $81.65^{\mathrm{a}}$ & 0.31 & 0.04 \\
d 28 & & & & & & \\
DM & $74.66^{\mathrm{b}}$ & $75.16^{\mathrm{ab}}$ & $74.79^{\mathrm{b}}$ & $76.12^{\mathrm{a}}$ & 0.42 & 0.04 \\
N & 67.81 & 67.73 & 67.90 & 68.22 & 0.35 & 0.38 \\
EE & $77.20^{\mathrm{b}}$ & $79.60^{\mathrm{a}}$ & $77.96^{\mathrm{b}}$ & $79.95^{\mathrm{a}}$ & 0.46 & 0.02 \\
GE & 80.35 & 80.87 & 80.24 & 80.58 & 0.33 & 0.86 \\
\hline
\end{tabular}

SEM, pooled standard error of the means; DM, dry matter; $N$, nitrogen; $E E$, ether extract; $G E$, gross energy; $M E$, metabolizable energy.

1) Each mean represents 10 replications with 18 chicks per replication.

${ }^{2)} \mathrm{RET}$, reduced energy treatment (ME $=2,950$ and 3,100 kcal//kg for starter and finisher diet); BDT, basal diet treatment (ME $=3,050$ and 3,200 kcal $/ \mathrm{kg}$ for starter and finisher diet); RET015, RET+0.15 g/kg lipase; RET03, RET+0.3 g/kg lipase.

${ }_{a, b}$ Means in the same row with different superscripts differ $(p<0.05)$.

or HDL-C concentrations were not influenced ( $\mathrm{p}>0.05)$ by dietary treatments. Broilers in RET015 and RET03 treatments had lower $(\mathrm{p}<0.05)$ levels of LDL-C than those in BDT treatment. The TG concentration was decreased $(p<0.05)$ by RET03 treatment compared with BDT treatment.

\section{Jejunum villi histology}

Broilers fed RET03 diet had greater $(\mathrm{p}<0.05) \mathrm{VH}$ than those fed RET and BDT diets (Table 5), and higher ( $<<0.05)$ VH:CD ratio compared with other treatments. Dietary treatments did not affect ( $\mathrm{p}>0.05) \mathrm{CD}$.

Table 4. Effect of diets with different energy and lipase levels on serum profiles in broilers ${ }^{1)}$

\begin{tabular}{lcccccc}
\hline $\begin{array}{c}\text { Item } \\
(\mathbf{m g} / \mathbf{d L})\end{array}$ & RET $^{2)}$ & BDT $^{2)}$ & RET015 $^{2)}$ & RET03 $^{2)}$ & SEM & p-value \\
\hline d 14 & & & & & & \\
TC & $118.6^{\mathrm{ab}}$ & $126.6^{\mathrm{a}}$ & $115.4^{\mathrm{b}}$ & $112.4^{\mathrm{b}}$ & 3.20 & 0.02 \\
TG & $87.0^{\mathrm{b}}$ & $91.9^{\mathrm{a}}$ & $84.3^{\mathrm{b}}$ & $84.5^{\mathrm{b}}$ & 1.64 & 0.04 \\
HDL-C & 89.0 & $94.2^{2}$ & $87.2^{\mathrm{a}}$ & $85.1^{\mathrm{a}}$ & 3.55 & 0.26 \\
LDL-C & $26.3^{\mathrm{b}}$ & $29.8^{\mathrm{a}}$ & $24.9^{\mathrm{bc}}$ & $22.2^{\mathrm{c}}$ & 1.03 & 0.03 \\
d 28 & & & & & & \\
TC & 127.0 & 127.4 & 122.5 & 117.3 & 3.50 & 0.32 \\
TG & $85.6^{\mathrm{ab}}$ & $90.8^{\mathrm{a}}$ & $80.3^{\mathrm{ab}}$ & $78.7^{\mathrm{b}}$ & 3.19 & 0.04 \\
HDL-C & 91.5 & 92.8 & 90.4 & 88.7 & 2.62 & 0.46 \\
LDL-C & $23.0^{\mathrm{ab}}$ & $26.5^{\mathrm{a}}$ & $22.3^{\mathrm{b}}$ & $20.0^{\mathrm{b}}$ & 1.33 & 0.02 \\
\hline
\end{tabular}

SEM, pooled standard error of the means; TC, total cholesterol; TG, triglyceride; HDL-C, high-density lipoprotein cholesterol; LDL-C, low-density lipoprotein cholesterol; ME, metabolizable energy.

1) Each mean represents 10 replications with 4 chicks per replication.

2) $\mathrm{RET}$, reduced energy treatment (ME $=2,950$ and 3,100 kcal/kg for starter and finisher diet); $B D T$, basal diet treatment (ME $=3,050$ and 3,200 kcal $/ \mathrm{kg}$ for starter and finisher diet); RET015, RET+0.15 g/kg lipase; RET03, RET+0.3 g/kg lipase.

$a, b$ Means in the same row with different superscripts differ $(p<0.05)$.
Table 5. Effect of diets with different energy and lipase levels on jejunum villus histology in broilers ${ }^{1)}$

\begin{tabular}{lcccccc}
\hline Item & RET $^{2)}$ & BDT $^{2)}$ & RETO15 $^{2)}$ & RET03 $^{2)}$ & SEM & p-value \\
\hline VH $(\mu \mathrm{m})$ & $778^{\mathrm{b}}$ & $807^{\mathrm{b}}$ & $827^{\mathrm{ab}}$ & $911^{\mathrm{a}}$ & 32 & 0.03 \\
$\mathrm{CD}(\mu \mathrm{m})$ & 114 & 129 & 120 & 106 & 8.0 & 0.14 \\
VH:CD ratio & $6.82^{\mathrm{b}}$ & $6.26^{\mathrm{b}}$ & $6.89^{\mathrm{b}}$ & $8.59^{\mathrm{a}}$ & 0.38 & 0.01 \\
\hline
\end{tabular}

SEM, pooled standard error of the means; $V H$, villus height; $C D$, crypt depth; $M E$, metabolizable energy.

1) Each mean represents 10 replications with 4 chicks per replication.

${ }^{2)}$ RET, reduced energy treatment (ME $=2,950$ and 3,100 kcal $/ \mathrm{kg}$ for starter and finisher diet); BDT, basal diet treatment (ME $=3,050$ and 3,200 kcal/kg for starter and finisher diet); RET015, RET+0.15 g/kg lipase; RET03, RET+0.3 g/kg lipase.

$a, b$ Means in the same row with different superscripts differ $(p<0.05)$.

\section{Digestive enzyme activities}

The activity of pancreatic lipase in BDT and RET03 treatments was higher $(\mathrm{p}<0.05)$ than that in RET treatment (Table 6). There was no difference $(p>0.05)$ in the activity of sucrose or maltase in jejunum as well as amylase or trypsin in pancreas among treatments.

\section{Carcass quality}

The relative weight of abdominal fat was higher $(\mathrm{p}<0.05)$ in BDT treatment compared with RET015 and RET03 treatments (Table 7). Breast muscle color (lightness, redness, and yellowness), $\mathrm{pH}$ value, as well as the percentage of WHC, drip loss, liver, spleen, bursa of fabricius, breast muscle, and gizzard were not influenced $(\mathrm{p}>0.05)$ by dietary treatments.

\section{DISCUSSION}

\section{Growth performance}

The great improvement in genetics and intensive production of broilers required a high energy level diet to express their genetic potential [26]. In commercial production, lipids (fats and oils) are used in broiler feed because the energy value of lipids is reported to be at least twice as those of carbohydrates and proteins [18]. However, the immature physiological functions and deficient secreted lipase may lead to the poor digestion

Table 6. Effect of diets with different energy and lipase levels on digestive enzyme activity in broilers ${ }^{1)}$

\begin{tabular}{lcccccc}
\hline \multicolumn{1}{c}{ Item } & RET $^{2)}$ & BDT $^{2)}$ & RET015 $^{2)}$ & RET03 $^{2)}$ & SEM & p-value \\
\hline Sucrase & 301 & 288 & 306 & 328 & 26.0 & 0.44 \\
Maltase & 1,686 & 1,712 & 1,672 & 1,697 & 183.5 & 0.76 \\
Amylase & 1,008 & 1,156 & 1,065 & 1,108 & 165.5 & 0.87 \\
Trypsin & 8.35 & 11.51 & 10.38 & 11.20 & 2.71 & 0.53 \\
Lipase & $0.65^{\mathrm{b}}$ & $0.86^{\mathrm{a}}$ & $0.79^{\mathrm{ab}}$ & $0.84^{\mathrm{a}}$ & 0.06 & 0.04 \\
\hline
\end{tabular}

SEM, pooled standard error of the means; ME, metabolizable energy.

${ }^{1)}$ Each mean represents 10 replications with 4 chicks per replication.

${ }^{2)} \mathrm{RET}$, reduced energy treatment (ME $=2,950$ and 3,100 kcal $/ \mathrm{kg}$ for starter and finisher diet); BDT, basal diet treatment (ME = 3,050 and 3,200 kcal $/ \mathrm{kg}$ for starter and finisher diet); RET015, RET+0.15 g/kg lipase; RET03, RET+0.3 g/kg lipase.

$a, b$ Means in the same row with different superscripts differ $(p<0.05)$. 
Table 7. Effect of diets with different energy and lipase levels on carcass quality in broilers ${ }^{11}$

\begin{tabular}{|c|c|c|c|c|c|c|}
\hline Item & $\mathrm{RET}^{2)}$ & $\mathrm{BDT}^{2)}$ & RET015 ${ }^{2)}$ & RETO3 $^{2)}$ & SEM & p-value \\
\hline \multicolumn{7}{|l|}{ Breast muscle color } \\
\hline Lightness $\left(L^{\star}\right)$ & 55.30 & 55.14 & 55.43 & 56.06 & 1.51 & 0.69 \\
\hline Redness $\left(a^{*}\right)$ & 14.90 & 15.23 & 15.04 & 13.80 & 0.45 & 0.12 \\
\hline Yellowness $\left(b^{*}\right)$ & 8.24 & 8.70 & 8.55 & 9.00 & 0.48 & 0.78 \\
\hline Water holding capacity (\%) & 60.70 & 61.51 & 62.10 & 61.14 & 0.63 & 0.54 \\
\hline $\mathrm{pH}$ & 5.48 & 5.49 & 5.45 & 5.40 & 0.05 & 0.10 \\
\hline \multicolumn{7}{|l|}{ Drip loss (\%) } \\
\hline d 1 & 2.48 & 3.09 & 2.46 & 2.16 & 0.39 & 0.07 \\
\hline d 3 & 7.45 & 7.41 & 7.34 & 7.77 & 0.66 & 0.65 \\
\hline d 5 & 12.04 & 13.21 & 11.93 & 12.47 & 0.77 & 0.45 \\
\hline$d 7$ & 15.38 & 15.55 & 14.97 & 16.98 & 0.80 & 0.35 \\
\hline \multicolumn{7}{|l|}{ Relative organ weight (\%) } \\
\hline Liver & 2.78 & 2.92 & 2.75 & 2.56 & 0.12 & 0.15 \\
\hline Spleen & 0.12 & 0.12 & 0.10 & 0.12 & 0.01 & 0.78 \\
\hline Bursa of fabricius & 0.16 & 0.15 & 0.18 & 0.17 & 0.01 & 0.08 \\
\hline Breast muscle & 16.76 & 17.59 & 17.66 & 18.55 & 0.77 & 0.19 \\
\hline Abdominal fat & $1.60^{\mathrm{ab}}$ & $1.72^{\mathrm{a}}$ & $1.50^{b}$ & $1.35^{b}$ & 0.06 & 0.04 \\
\hline Gizzard & 0.87 & 0.89 & 0.84 & 0.95 & 0.05 & 0.20 \\
\hline
\end{tabular}

SEM, pooled standard error of the means; ME, metabolizable energy.

${ }^{1)}$ Each mean represents 10 replications with 4 chicks per replication.

2) RET, reduced energy treatment (ME $=2,950$ and 3,100 kcal/ $/ \mathrm{kg}$ for starter and finisher diet); BDT, basal diet treatment (ME = 3,050 and 3,200 kcal/kg for starter and finisher diet); RET015, RET+0.15 g/kg lipase; RET03, RET+0.3 g/kg lipase.

$a, b$ Means in the same row with different superscripts differ $(p<0.05)$.

and absorption of lipids in young broilers [8]. In general, animal fat rich in saturated fatty acids are digested less easily than vegetable oil rich in unsaturated fatty acids [6]. Lipase has the potential to improve the utilization of lipids, especially animal fats. Therefore, tallow (melting point, $43^{\circ} \mathrm{C}$; saturated fatty acids, $49.4 \%$; monounsaturated fatty acids $42.1 \%$; and polyunsaturated fatty acids, $3.0 \%$ of the total fat) was used to determine whether lipase supplementation can exert beneficial effects on broilers in this study. Increased BWG during d 1 to 14 of broilers fed basal diet observed in the current study were in agreement with previous data which demonstrated that BWG was higher in basal diet treatments compared with reduced energy diet treatments (100 kcal/kg ME lower) including tallow [7]. Decreased BWG in response to reduced energy diet (100 kcal/kg ME lower) was also observed in broilers [27]. Notwithstanding, previous studies also reported increased FCR in reduced energy diet compared with basal energy diet $[7,27]$, which was inconsistent with our result. The energy was firstly used for maintenance if broilers were fed reduced energy diet, and therefore the growth might be restricted. It can explain the decreased BWG in the current study. However, we failed to observe the positive effect on FI in response to energy, which was consistent with some previous studies [7]. In contrast, a study indicated that FI was also increased by feeding high energy diets in broilers [27]. Energy-reduced diet (150 $\mathrm{kcal} / \mathrm{kg}$ ME lower) decreased FI only during d 22 to 35 in broilers [10]. Although broilers might control energy intake by adjusting their FI according to energy level, broilers selected both for rapid weight gain and muscular mass deposition did not properly regulate voluntary FI as diet energy concentration changed [28]. Several researches also identified the noneffect of dietary energy on FI [29,30]. This may be the reason for FI not being affected in the herein study. Importantly, broilers fed reduced energy diets supplemented with lipase $(3,000$ $\mathrm{U} / \mathrm{kg}$ feed) had higher BWG from d 1 to 14 and lower FCR throughout the experiment compared with reduced energy diet, which even achieved the level of basal energy diet. Lipase addition (50,000 U/kg feed) increased ADG and ADFI, but did not affect FCR in broilers fed diets containing 25\% high oleic acid sunflower seed [31]. Increased ADG and decreased FCR in weanling pigs fed diets containing $3 \%$ soybean oil with lipase $(9,000 \mathrm{U} / \mathrm{kg}$ feed) was observed, which was similar with our results [32]. On the contrary, FI and BWG decreased linearly with increasing dietary concentration of lipase $(0$ to $11,250,000 \mathrm{U} / \mathrm{kg}$ feed) in broilers fed diets containing $4 \%$ animal-vegetable blended fat during $\mathrm{d} 1$ to 21 [8], while BWG or FI was not influenced from d 21 to 42 or d 1 to 42 . BWG, FI, or FCR were not affected by lipase addition (100 U/kg feed) in broilers fed 5\% tallow or canola oil [33]. No effect of lipase addition (100 U/kg feed) on growth performance was noted in broilers ( 4 to $18 \mathrm{~d}$ ) fed $5 \%$ canola oil, which may be due to the low supplementation level and short time [34]. From researches mentioned above, we hypothesize that the inconsistent results of growth performance were due to diet fat sources, 
lipase types and levels. However, there were few reports about the use of lipase in broilers' diets and therefore more studies are needed to evaluate the effects of lipase on broilers.

\section{Nutrient digestibility}

It was well documented that pancreatic lipase presents specificity for the fatty acids esterified to glycerol in the 1- and 3 - positions and absorbed the 2-monoglycerides intact [35]. However, the 2-position long-chain saturated fatty acid in the form of monoglycerides are more nonpolar and insoluble and thus less digestible [6]. Tallow had lower fat digestibility due to the esterified positions of palmitic and stearic acids at the 1and 3-positions and oleic acid at the 2-pisition [36]. Therefore, the tallow-containing diets were used in this study to determine whether the lipase can exert beneficial effects on nutrient digestibility. The present study found that the ATTD of DM, $\mathrm{N}, \mathrm{EE}$, and GE on $\mathrm{d} 14$ as well as DM and EE on d 28 was increased in reduced energy diets supplemented with lipase (3,000 U/kg feed). Increased apparent ME and EE digestibility occurred with increasing lipase supplementation (0 to $11,250,000 \mathrm{U} / \mathrm{kg}$ feed) in broilers fed diets containing $4 \%$ animal-vegetable blended fat [14]. We attributed the increased ATTD of DM and GE to the increased ATTD of EE in this study. Increased EE digestibility in broilers fed diets containing $25 \%$ high oleic acid sunflower seed with lipase addition $(50,000 \mathrm{U} / \mathrm{kg}$ feed) was observed [31]. Furthermore, the improvement in nutrient digestibility may partially mirror the increased FCR in RET03 treatment in the current study. EE digestibility was not increased by the incorporation of lipase (100 U/kg feed) into tallow-containing diets in broilers [33]. Lipase addition (100 U/kg feed) did not affect ATTD of EE or ileum EE digestibility in broilers ( 4 to $18 \mathrm{~d}$ ) fed 5\% canola oil [34]. These authors suggested that the insufficiency of pancreatic lipase production may not contribute to the lower fat digestibility. It was noteworthy that the ATTD of DM, GE, N, or EE in reduced energy diets was not significantly different compared with the basal diet. On the contrary, ATTD of DM, $\mathrm{EE}$, and GE in reduced energy diet (100 kcal/kg ME lower) was decreased because higher fat can slow down the passage of digesta and thus increase digestion and absorption of nutrients [37].

\section{Serum profiles}

Reports about the effect of lipase on blood profile in broilers are limited. TG was fatty acid trimesters of glycerol and came from food as well as being produced by the body. They were secreted from the liver into the blood by TG-rich lipoproteins. TC was converted into bile acid in the liver, which is the main way to remove cholesterol from the body. N-3 fatty acid can restrain TG synthesis and secretion of LDL to maintain the low-level of TG. In this study, TC, TG, and LDL-C on d 14 as well as TG and LDL-C on $\mathrm{d} 28$ was decreased by lipase supple- mentation. This may be due to polyunsaturated fatty acid form tallow hydrolysis by lipase. It has been suggested that the faster rates of absorption and metabolism of ingested fat may be the reason for lower serum TGs in broilers fed lipase, which may be mirrored by the increased EE digestibility and decreased abdominal fat in our result. However, TC, HDL-C, or TG levels were not affected by dietary fat sources (soybean oil, poultry fat, and a blend of $50 \%$ soybean oil and $50 \%$ poultry fat) or emulsifier addition in broilers [38]. High levels of TC, TG, and LDL-C indicated that lipase supplementation may be beneficial to serum fat metabolism in the current study [39]. Due to the lack of studies on lipase in serum lipid profiles of broilers, the results were compared with emulsifiers or pigs. The decreased TC, TG, or LDL-C by several emulsifiers in broilers was demonstrated [7], which was in agreement with our study. Lipase supplementation $(9,000 \mathrm{U} / \mathrm{kg}$ feed) decreased TG and LDL-C, but did not affect TC in weaning pigs fed 3\% soybean oil diets [32]. More studies are needed to find out the mechanism affecting lipase in serum profiles.

\section{Jejunum villi histology}

It has been suggested that lipase supplementation ( 0 to $11,250,000$ $\mathrm{U} / \mathrm{kg}$ feed) in broilers fed diets containing $4 \%$ animal-vegetable blended fat had no effect on gut morphology [8]. In contrast, we observed increased $\mathrm{VH}$ and $\mathrm{VH}: \mathrm{CD}$ in reduced energy diets with lipase supplementation (3,000 U/kg feed), indicating an increase in the digestive and absorptive capacity of the small intestine in response to the greater flow of nutrients for optimal growth of broilers. Additionally, this may also be responsible for the improved nutrient digestibility. $\mathrm{VH}$ was associated with the absorption capacity of the enterocytes, and the short villi may decrease the surface area for nutrient absorption [40]. Notwithstanding this, reduced energy diets (50 to $100 \mathrm{kcal} / \mathrm{kg}$ ME lower) decreased jejunum VH and CD in broilers [41], which was inconsistent with our results. In contrast, many studies indicated the positive effects of enzyme supplementation on gut morphology in birds $[41,42]$. The supplemental lipase $(9,000 \mathrm{U} / \mathrm{kg}$ feed $)$ in weanling pigs' diets containing $3 \%$ soybean oil increased VH, VH:CD ratio, and decreased CD in duodenum and jejunum [32]. To the best of our knowledge, this was the first study regarding lipase and jejunum villi histology. Additonal investigations are needed to study the effects of lipase on gut morphology in broilers.

\section{Digestive enzyme activities}

Lipase supplementation $(9,000 \mathrm{U} / \mathrm{kg}$ feed) to weaning pigs' diets containing $3 \%$ soybean oil improved the activities of lipase and amylase in pancreas and duodenum [32]. Our results showed that lipase addition $(3,000 \mathrm{U} / \mathrm{kg}$ feed) into reduced energy diets increased the activities of pancreatic lipase in broilers. Furthermore, the activity of sucrase or maltase in jejunum as well as amylase or trypsin in pancreas was not affected by 
lipase addition in the current study. Several studies demonstrated the positive effect of enzyme supplementation (xylanase or $\beta$-glucosidase) on digestive enzyme activities of small intestine in broilers $[43,44]$, although some studies found no differences in digestive enzyme activities with enzyme supplementation $[42,45]$. In this study, digestive enzyme activities were determined on $28 \mathrm{~d}$ of age. It can be speculated that this may partly be the reason for the absence of an effect of lipase on digestive enzyme activities except pancreas lipase, because the digestive enzyme activities may be less affected by the dietary manipulation in adult birds than in young birds [42]. Further studies are needed to verify this hypothesis.

\section{Carcass quality}

The percentage weight of the liver was increased with lipase supplementation (0 to $11,250,000 \mathrm{U} / \mathrm{kg}$ feed) in broilers fed diets containing $4 \%$ animal-vegetable blended fat on $\mathrm{d} 21$, and the increased liver weight may be due to the increased metabolic activity related to lipid utilization [8]. Broilers fed high ME diets (50 kcal/kg ME higher) had decreased relative weight of liver compared with those fed low ME diets on d 21 [41]. In contrast, we failed to observe any effect of dietary treatments on the relative liver percentage. Abdominal fat percentage was increased with increasing dietary ME levels $[42,46]$, which was also demonstrated in our result. Lipid accumulation in the bodies of broilers may be increased by high energy diets, which can lead to higher abdominal fat percentage in broilers fed basal diet compared with reduced energy diet [47]. Interestingly, the supplementation of lipase in reduced energy diet further decreased abdominal fat compared with basal diet in this study. However, no effect of lipase supplementation (50,000 $\mathrm{U} / \mathrm{kg}$ feed) on abdominal fat in broilers fed diets containing $25 \%$ high oleic acid sunflower seed was observed [31]. In agreement with our results, the reduced energy diet $(100 \mathrm{kcal} / \mathrm{kg}$ ME lower) had no effect on the breast muscle color, $\mathrm{pH}$ value, WHC, drip loss, or relative organ weight in broilers fed diets containing $1.25 \%$ to $3.61 \%$ tallow [37]. Further studies should focus on the mechanism of the lipase on the abdominal fat percentage, intramuscular fat percentage, and liver percentage.

\section{CONCLUSION}

Considering the data obtained herein and the above discussion, it can be concluded that lipase supplementation $(0.3 \mathrm{~g} / \mathrm{kg}$ feed) increased BWG, the ATTD of DM, N, EE, and GE, while it decreased FCR, the TG and LDL-C concentrations during d 1 to 14, as well as increased ATTD of DM and EE, but decreased FCR, TG, and LDL-C concentrations during $\mathrm{d} 15$ to 28 in broilers fed reduced energy diet. Furthermore, lipase supplementation $(0.3 \mathrm{~g} / \mathrm{kg}$ feed $)$ increased the pancreatic lipase activity, $\mathrm{VH}$ and $\mathrm{VH}: \mathrm{CD}$ ratio, while decreased FCR and the relative abdominal fat percentage during the overall experi- ment. Lipase supplementation in the reduced energy diet may be economical for broiler production.

\section{CONFLICT OF INTEREST}

We certify that there is no conflict of interest with any financial organization regarding the material discussed in the manuscript.

\section{ACKNOWLEDGMENTS}

This work was supported by the Sichuan international cooperation project (18GJHZ0217).

\section{REFERENCES}

1. Emmerson DA. Commercial approaches to genetic selection for growth and feed conversion in domestic poultry. Poult Sci 1997;76:1121-5.

2. Classen HL. Diet energy and feed intake in chickens. Anim Feed Sci Technol 2017;233:13-21.

3. Wiseman J, Lewis CE. Influence of dietary energy and nutrient concentration on the growth of body weight and carcass components of broiler chickens. J Agric Sci 1998;131:361-71.

4. Villaverde C, Baucells MD, Cortinas L, Barroeta AC. Effects of dietary concentration and degree of polyunsaturation of dietary fat on endogenous synthesis and deposition of fatty acids in chickens. Br Poult Sci 2006;47:173-9.

5. Smink W, Gerrits WJJ, Hovenier R, et al. Effect of dietary fat sources on fatty acid deposition and lipid metabolism in broiler chickens. Poult Sci. 2010;89:2432-40.

6. Danicke S. Interaction between cereal identity and fat quality and content in response to feed enzymes in broilers. In: Bedford MR, Partridge GG, editors. Enzymes in farm animal nutrition. Wallingford, UK: CABI Pub,; 2001. pp. 199-236.

7. Zhao PY, Kim IH. Effect of diets with different energy and lysophospholipids levels on performance, nutrient metabolism, and body composition in broilers. Poult Sci 2017;96:1341-7.

8. Al-Marzooqi W, Leeson S. Effect of dietary lipase enzyme on gut morphology, gastric motility, and long-term performance of broiler chicks. Poult Sci 2000;79:956-60.

9. Noy Y, Sklan D. Digestion and absorption in the young chick. Poult Sci 1995;74:366-73.

10. Cho JH, Zhao PY, Kim IH. Effects of emulsifier and multienzyme in different energy density diet on growth performance, blood profiles, and relative organ weight in broiler chickens. J Agric Sci 2012;4:161-8.

11. Jansen M, Nuyens F, Buyse J, Leleu S, Van Campenhout L. Interaction between fat type and lysolecithin supplementation in broiler feeds. Poult Sci 2015;94:2506-15.

12. Wang JP, Zhang ZF, Yan L, Kim IH. Effects of dietary supplementation of emulsifier and carbohydrase on the growth per- 
formance, serum cholesterol and breast meat fatty acids profile of broiler chickens. Anim Sci J 2016;87:250-6.

13. Adeola O, Cowieson AJ. Board-invited review: opportunities and challenges in using exogenous enzymes to improve nonruminant animal production. J Anim Sci 2011;89:3189-218.

14. Al-Marzooqi W, Leeson S. Evaluation of dietary supplements of lipase, detergent, and crude porcine pancreas on fat utilization by young broiler chicks. Poult Sci 1999;78:1561-6.

15. Nagargoje S, Dhumal MV, Nikam MG, Khose KK. Effect of crude soy lecithin with or without lipase on performance and carcass traits, meat keeping quality and economics of broiler chicken. Int J Livest Res 2016;6:46-54.

16. Francesch M, Geraert P. Enzyme complex containing carbohydrases and phytase improves growth performance and bone mineralization of broilers fed reduced nutrient cornsoybeanbased diets. Poult Sci 2009;88:1915-24.

17. Zhou Y, Jiang Z, Lv D. Improved energy-utilizing efficiency by enzyme preparation supplement in broiler diets with different metabolizable energy levels. Poult Sci 2009;88:316-22.

18. National Resource Council. Nutrient requirements of poultry. 9th rev. ed. Washington, DC, USA: National Academy Press; 1994.

19. Fenton TW, Fenton M. An improved method for chromic oxide determination in feed and feces. Can J Anim Sci 1979;59:631-4.

20. AOAC. Official methods of analysis of the association of official analytical chemists international, 18th ed. Gaithersburg, MD, USA: AOAC International; 2007.

21. Lu P, Li DF, Yin JD, Zhang LY, Wang ZY. Flavor differences of cooked longissimus muscle from Chinese indigenous pig breeds and hybrid pig breed (Duroc $\times$ Landrace $\times$ Large White). Food Chem 2008;107:1529-37.

22. Williams CH, David DJ, llismaa O. The determination of chromic oxide in feces samples by atomic absorption spectrophotometry. J Agric Sci 1962;59:381-5.

23. Kauffman RG, Eikelenboom G, van der Wal PG, Engel B, Zaar M. A comparison of methods to estimate water holding capacity in post-rigor porcine muscle. Meat Sci 1986;18:307-22.

24. Honikel KO. Reference methods for the assessment of physical characteristic of meat. Meat Sci 1998;49:447-57.

25. Sell JL, Angel CR, Piquer FJ, Mallarino EG, As-Gatshan HA. Development patterns of selected characteristics of the gastrointestinal tract of young turkeys. Poult Sci 1991;70:1200-5.

26. Maiorka A, Dahlke F, Santin E, Kessler AM, Jr AMP. Effect of energy levels of diets formulated on total or digestible amino acid basis on broiler performance. Rev Bras Cienc Avic 2004;6: 87-91.

27. Niu ZY, Shi JS, Liu FZ, et al. Effects of dietary energy and protein on growth performance and carcass quality of broilers during starter phase. Int J Poult Sci 2009;8:508-11.

28. Dozier WA, Kidd MT, Corzo A, Anderson J, Branton SL. Growth performance, meat yield, and economic responses of broilers fed diets varying in metabolizable energy from thirty to fifty-nine days of age. J Appl Poult Res 2006;15:367-82.

29. Li W, Guo Y, Chen J, et al. Influence of lighting schedule and nutrient density in broiler chickens: effect on growth performance, carcass traits and meat quality. Asian-Australas J Anim Sci 2010;23:1510-8.

30. Mbajiorgu CA, Ngambi JW, Norris DD. Voluntary feed intake and nutrient composition in chickens. Asian J Anim Vet Adv 2011;6:20-8.

31. Brenes A, Centeno C, Viveros A, Arija I. Effect of enzyme addition on the nutritive value of high oleic acid sunflower seeds in chicken diets. Poult Sci 2008;87:2300-10.

32. Chen SY, Liu ZX, He YD, Chu C, Wang MQ. Effect of coated lipase supplementation on growth, digestion and intestinal morphology in weaning piglets. J Anim Vet Adv 2014;13:10937.

33. Meng X, Slominski BA, Guenter W. The effect of fat type, carbohydrase, and lipase addition on growth performance and nutrient utilization of young broilers fed wheat-based diets. Poult Sci 2004;83:1718-27.

34. Slominski BA, Meng X, Jia W, Guenter W, Jones O. The effect of lipase, amylase and protease addition on growth performance and nutrient digestion in young broiler chickens. EPC 200612th European Poultry Conference. Verona, Italy: World's Poultry Science Association (WPSA); 2006. pp. 10-4.

35. Leeson S, Summers JD. Scott's nutrition of the chicken. 4th ed. Guelph, ON, Canada: University of Guelph; 2001.

36. Sibbald IR, Kramer JKG. The true metabolizable energy values of fats and fat mixtures. Poult Sci 1977;56:2079-86.

37. Upadhaya SD, Park JW, Park JH, Kim IH. Efficacy of 1,3-diacylglycerol as a fat emulsifier in low-density diet for broilers. Poult Sci 2017;96:1672-8.

38. Neto ACG, Pezzato AC, Sartori JR, et al. Emulsifier in broiler dietscontaining different fat sources. Braz J Poult Sci 2011;13: 119-25.

39. Ao X, Yoo JS, Zhou TX, et al. Effects of fermented garlic powder supplementation on growth performance, blood profiles and breast meat quality in broilers. Livest Sci 2011;141:85-9.

40. Parsaie S, Shariatmadari F, Zamiri MJ, Khajeh K. Influence of wheat-based diets supplemented with xylanase, bile acid and antibiotics on performance, digestive tract measurements and gut morphology of broilers compared with a maizebased diet. Br Poult Sci 2007;48:594-600.

41. Zhu HL, Hu LL, Hou YQ, Zhang J, Ding BY. The effects of enzyme supplementation on performance and digestive parameters of broilers fed corn-soybean diets. Poult Sci 2014;93: 1704-12.

42. Liu WC, Kim IH. Effects of dietary xylanase supplementation on performance and functional digestive parameters in broilers fed wheat-based diets. Poult Sci 2017;96:566-73.

43. Engberg RM, Hedemann MS, Steenfeldt S, Jensen BB. Influence of whole wheat and xylanase on broiler performance and microbial composition and activity in the digestive tract. Poult 
Sci 2004;83:925-38.

44. Qian LC, Sun JY. Effect of $\beta$-glucosidase as a feed supplementary on the growth performance, digestive enzymes and physiology of broilers. Asian-Australas J Anim Sci 2009;22:260-6.

45. Luo D, Yang F, Yang X, et al. Effects of xylanase on performance, blood parameters, intestinal morphology, microflora and digestive enzyme activities of broilers fed wheat-based diets. Asian-Australas J Anim Sci 2009;22:1288-95.
46. Zaman QU, Mushtaq T, Nawaz H, et al. Effect of varying dietary energy and protein on broiler performance in hot climate. Anim Feed Sci Technol 2008;146:302-12.

47. Nahashon SN, Adefope N, Amenyenu A, Wright D. Effects of dietary metabolizable energy and crude protein concentrations on growth performance and carcass characteristics of French guinea broilers. Poult Sci 2005;84:337-44. 